\title{
BIOREACTOR LANDFILL AND CLEANER PRODUCTION AS ADEQUATE TOOLS FOR THE REMEDIATION OF PALESTINIAN LANDFILLS
}

\author{
Rashed Al-Sa'ed \\ Institute for Water Studies, Birzeit University, Palestine
}

\begin{abstract}
Municipal landfills remain the predominant and most economical method of waste disposal in Palestine; however present some potential public and environmental threats. This paper proposes a suggested bioreactor landfill project and presents the cleaner production as adequate remediation strategies for Palestinian landfills aiming at environmental protection and expansion of the landfills life cycle. The case of Ramallah municipal landfill (RML), one of the largest old uncontrolled, dumpsite in Palestine is discussed. The leachate quantity, characteristics, possible environmental impacts, leachate treatment and disposal and reasonable remediation options were investigated. Despite high organic contents in the municipal waste, the climate in Ramallah district (small annual rainfall, high evaporation rates and warm temperature) tends to produce concentrated leachate and small leachate quantities. However, infiltration and discharge of both leachate and stormwater without a prior reasonable treatment give rise to serious environmental problems including aquatic and public health risks. Containment of old dumpsites, applying a bioreactor landfill approach with leachate treatment and recycling, waste recycling and cleaner production in the industrial sector form sustainable options for environmental protection. Lastly, the feasibility and cost effectiveness of possible remediation options are analyzed.
\end{abstract}

\section{KEY WORDS}

bioreactor landfill, cleaner production, environmental protection, leachate treatment, old site bioremediation, Palestinian landfills, waste reduction

\section{INTRODUCTION}

Each of Palestine's 3 million people generates over $0.85 \mathrm{~kg}$ of municipal solid waste (MSW) per day, for a yearly countrywide total of around 1 million ton. Since the passage of the 1999 Environmental Act, recycling has not grown yet dramatically and Palestine still experiences a substantial increment in landfilling. In 1997, of the 1 million ton of 
KALMAR ECO-TECH'03

Bioremediation and Leachate Treatment

KALMAR, SWEDEN, November 25-27, 2003

MSW generated, 80 percent was landfilled, 15 percent was burned in open land, and less than 5 percent was recycled. In contrast, in 2003, of the 1.75 million tons of MSW generated, 75 percent was landfilled, 27 percent was bumed off, and about 3 percent was recycled. However, the per capita MSW generation rate and the country's population both continue to grow. Because of these growth factors, coupled modest anticipated improvements in the recycling rate, the total tons of waste landfilled will continue to rise and, in fact, will surpass the amount landfilled in 1997 in the near future.

To move Mediterranean countries (Jordan, Palestine and Israel) into the century of integrated and sustainable solid waste management, further reductions in landfilling are needed. One promising approach is the mass processing of municipal solid waste in "bioreactor" landfills. Under this model, landfills become "bioreactor" processing facilities where the waste is actively digested, rather than "dry tombs" where the waste decomposes slowly (Fig. 1). Using this approach, the life of landfills can be greatly extended, perhaps indefinitely. The proposed project will develop and demonstrate a scaled-up, fully instrumented landfill cell, engineered from the start as a bioreactor facility. The project would be constructed at Ramallah Municipal Landfill, with related works conducted at Birzeit University campus and the Sanitary Landfill of Albireh city (West Bank, Palestine). Both landfill sites in Ramallah and Albireh cities have been put into operation since 1977. These sites were neither designed as engineered sanitary landfills taking into account international environmental standards nor operated/monitored adequately to reduce possible negative impacts on public health and aquatic environment.

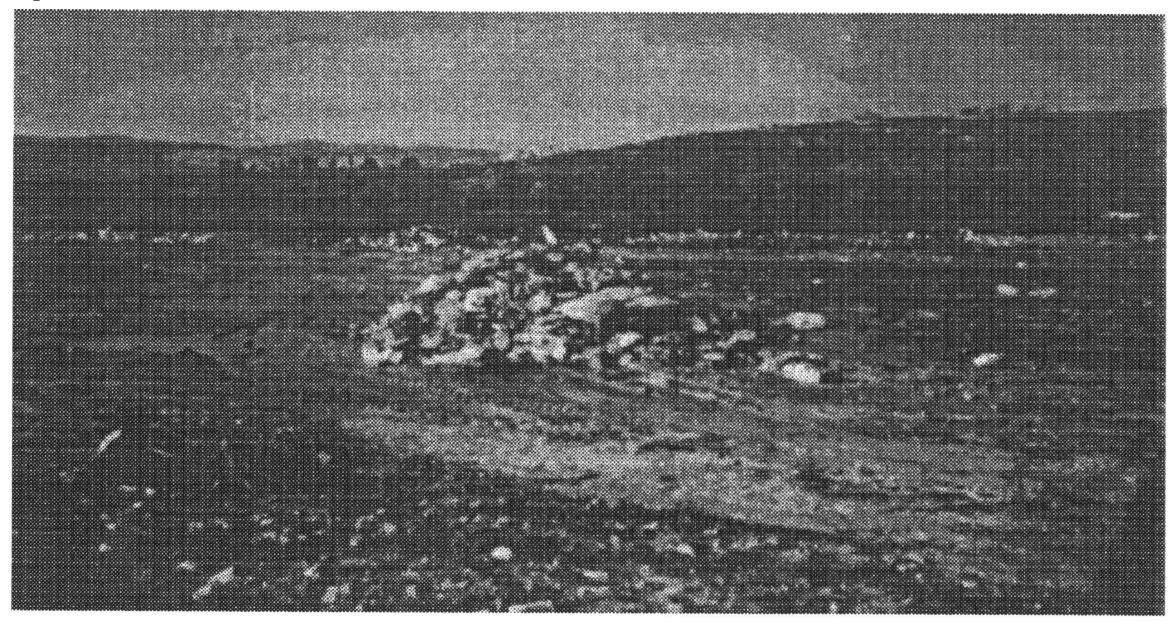

Figure 1. Open uncontrolled municipal dumpsite in Jenin District, West Bank, Palestine

The operation of municipal solid waste landfills as bioreactors has been practiced to some extent at many landfills throughout the United States (Reinhart and Townsend, 1997). The level to which bioreactor landfill operation has been implemented, however, has most commonly been limited to some form of leachate recirculation. Thus, experience is 
KALMAR ECO-TECH'03

Bioremediation and Leachate Treatment

KALMAR, SWEDEN, November 25-27, 2003

minimal with regard to: (a) controlling or monitoring the treatment process occurring within the landfill, and (b) the impact of the leachate recirculation on the internal landfill system.

The primary goal in pursuing landfill bioreactor technology is the operation of solid waste landfills in a manner resulting in accelerated stabilization of the waste. Landfill bioreactor operation includes, among other things, the addition of moisture to the solid waste to create an environment favorable for the microorganisms responsible for waste decomposition. approach of managing solid waste landfills in a fashion that discourages waste decomposition by minimizing moisture entrance into the landfill. A primary feature of landfill bioreactor is the recirculation of landfill leachate, or possibly other liquids, to the solid waste. The recirculation of leachate will be a major component of the bioreactor operation in this project.

A few studies have investigated areas of bioreactor landfill operation at the full-scale level beyond simple operation of leachate recirculation systems. One of the first systems was operated in Florida, at the Southwest Landfill in Alachua County. University of Florida researchers operated segments of the existing sanitary landfill as a bioreactor treatment system. However, the landfill was not designed with leachate recirculation in mind. A variety of leachate recirculation methods were employed (Townsend et al., 1995). Solid waste samples were collected from treated and untreated areas within the landfill, and the degree of waste treatment was measured (Miller et al., 1993). This research demonstrated that waste treatment was rapidly accelerated by leachate recirculation.

A small-scale, experimental bioreactor landfill system was recently constructed in Yolo County, California (Reinhart and Townsend, 1997). This facility, constructed in an area of $100 \mathrm{ft}$. by $100 \mathrm{ft}$, was designed to carry out leachate recirculation, and instrumentation was installed to measure leachate head on the liner and landfill temperature.

We will present a suggested project entailing application of bioreactor landfill with special emphasis on main goal, objectives, methodology and expected outputs. Further more, the experience in the field of cleaner production and waste recycling will also be presented and discussed. The Department of Technology/Kalmar University (DTKU) and the Institute for Water Studies (IWS) will select Albireh-Ramallah Landfills (ARAL), in the West Bank, Palestine, as the sites to conduct this demonstration project. This paper presents an initial plan for demonstrating bioreactor landfill technology in tow cells 1 and 2 at the ARAL. The demonstration will include the recirculation of leachate, the ability to inject air into the landfill, and the ability to collect the majority of the gaseous emissions from the landfill. The landfill bioreactor will be instrumented for the purpose of collecting in-situ measurements of such parameters as leachate head on the liner, moisture content and temperature of the waste. This project will result in a full-scale landfill being operated as a solid waste treatment system. The information and data collected will allow the technology to be fully evaluated as a method for managing solid waste in Palestine. 


\section{GOALS AND OBJECTIVES}

The primary goal of the landfill bioreactor demonstration project is to:

Design, construct, operate, and monitor a full-scale landfill bioreactor in Ramallah municipal landfill (RML) in a manner that permits a complete and fair evaluation of this technology as a method of solid waste management in Palestine, with appropriate consideration of science, engineering, environmental and economical issues.

The objectives of the landfill bioreactor demonstration are to:

- Design and operate an engineered bioreactor using innovative techniques and concepts.

- Design and operate the bioreactor in an appropriate manner to control and measure the major inputs and outputs.

- Evaluate the use of aerobic bioreactor landfill technology and compare the aerobic approach to the use of anaerobic bioreactor technology.

- Instrument the landfill bioreactor to permit in-situ monitoring of bioreactor activity and to measure previously unmeasured information (e.g. leachate head on the liner).

- Monitor the bioreactor in a manner to measure the impact of bioreactor activities and to allow control of the waste treatment process.

- Collect data through instrumentation, field monitoring, and laboratory analysis that will enable the project team to assess the success of the project, the feasibility of this technology for other sites, and to enable the future design and operation of landfill bioreactors in Palestine.

- Develop standardized design and operation procedures for this technology.

- Further define and quantify the true costs and benefits of landfill bioreactors.

- Provide a resource and training ground for students in the Palestinian University Systems, landfill operators, and engineers in Palestine and neighbouring countries.

\section{DESCRIPTION OF LANDFILL BIOREACTORAT ARAL}

\subsection{Overview}

The landfill bioreactor demonstration project at Albireh-Ramallah Landfill (ARAL) involves the modification of the existing landfill cells 1 and 2 . These cells are contiguous and form one large lined area of approximately $(0.1 \mathrm{ha})$. Approximately 0.20 ha (cell 1 and part of cell 2) will be dedicated as an active bioreactor area. A leachate recirculation system, an air injection system and a gas extraction system will be installed in this area. Instrumentation will be installed within the waste mass to assist in monitoring and control. Environmental sample collection and analysis, and field measurements, will be routinely performed to monitor the progress of bioreactor treatment. Instrumentation for 
KALMAR ECO-TECH'03

Bioremediation and Leachate Treatment

KALMAR, SWEDEN, November 25-27, 2003

measuring depth of leachate on the liner will be installed in a currently uncovered area of the cell 2-leachate collection system.

\subsection{Summary of Basic Project Components}

The basic components of the ARAL bioreactor demonstration project include:

- A leachate recirculation system of wells will be installed in all of cell 1 and part of cell 2 (for a total of $0.3 \mathrm{ha}$ ).

- The leachate collection system will be modified to allow collection of leachate from distinct areas within the landfill.

- A temporary membrane cap will be installed on the slopes and the top of the landfill area subjected to treatment.

- A combination air injection and gas extraction system will be installed. This will allow the landfill to be operated both aerobically and anaerobically. All gas emissions will be collected and characterized.

- Instrumentation, monitoring, and site management efforts will involve the ARAL administrative and operational staff, the researchers, and DoT staff.

The project researchers in cooperation with the landfill operators and their engineers will develop a bioreactor treatment strategy (amount of leachate recirculated, air injected, etc.). The research team will routinely monitor a number of landfill bioreactor parameters. This includes the collection of samples (leachate, gas, waste) and measurements of performance at the site (leachate and gas flow, settlement). Instrumentation will be installed in a number of locations in and around the landfill bioreactor. Unless otherwise instructed, the researchers (with proper training and with notification of the funding agency) will perform this monitoring. The monitoring parameters are as follows:

- Leachate quality and quantity

- Gaseous emissions quality and quantity

- Amounts of leachate recirculated

- Amounts of air injected

- Landfill settlement

- Characteristics of landfill waste

- Instrumented measurement (temperature, head on the liner, etc.)

\subsection{Site Management Plan}

As part of the design and permitting process, a detailed Site Management Plan will be developed. Information included in this Site Management Plan will include, at a minimum, the following: 
KALMAR ECO-TECH'03

Bioremediation and Leachate Treatment

KALMAR, SWEDEN, November 25-27, 2003

- A plan for routine operation of the bioreactor.

- A monitoring plan for ensuring the safe operation of the bioreactor.

- A schedule for meetings of project personnel.

- An identification of responsible parties.

- A procedure to coordinate research activities and visits to the site.

- A health and safety plan for project participants visiting or conducting work at the site.

\subsection{Research Activities}

Numerous research activities will be coordinated with the design, construction, and operation of the ARAL facilities. The objectives of the researchers will be incorporated during the design of the landfill bioreactor. Research activities will include instrumentation of the landfill as a means to collect valuable in-situ information about bioreactor performance. Responsibilities for the installation, operation, and upkeep of such instrumentation will be delineated during the design phase and developed as part of the detailed operations plan. The current plans for instrumentation are included in Table 1. The research will also involve the collection and analysis of numerous environmental samples (e.g. leachate, gas, waste), and the measurement of bioreactor performance in the field (e.g. settlement, gas flow). Current plans for routine monitoring are included in Table 2.

Table 1. Summary of instrumentation

\begin{tabular}{|l|l|}
\hline Instrumentation Location & Description \\
\hline $\begin{array}{l}\text { Liner and Leachate } \\
\text { Collection System in an area } \\
\text { of Cell 2 }\end{array}$ & $\begin{array}{l}\text { A series of pressure transducers will be installed directly on } \\
\text { top of the liner in cell 2. The purpose of the transducers will } \\
\text { be to measure the head, or depth of leachate, ponded on the } \\
\text { liner. Two different types of transducers will be evaluated. A } \\
\text { total of 64 stainless steel and 64 titanium transducers } \\
\text { (supplied by KPSI and Druck, respectively) will be } \\
\text { installed. Thirty of these transducers will be equipped with a } \\
\text { temperature measurement option. The installation will be } \\
\text { done in a 150 ft by 150 ft area in Cell 2. Five separate cross- } \\
\text { sections of the liner will be instrumented in this area. One of } \\
\text { these cross-sections will be a side by side comparison of the } \\
\text { stainless steel and the titanium transducers. }\end{array}$ \\
\hline $\begin{array}{l}\text { Monitoring Probes in } \\
\text { Bioreactor Area }\end{array}$ & $\begin{array}{l}\text { Monitoring probes will be installed in numerous locations in } \\
\text { the active bioreactor area. These probes will contain } \\
\text { instrumentation to help assess the degree of biological } \\
\text { activity, the movement of leachate, and the movement of }\end{array}$ \\
\hline
\end{tabular}




\begin{tabular}{|l|l|}
\hline & $\begin{array}{l}\text { gases. At various depths in these probes, instrumentation and } \\
\text { fluid conduit will be provided, including: } \\
\text { Moisture sensors to track the distribution of water as a } \\
\text { function of leachate recirculation activities and movement of } \\
\text { gases. } \\
\text { Temperature to track the degree of biological activity in the } \\
\text { waste. Temperature will also be a key parameter in } \\
\text { controlling the bioreactor operation. } \\
\text { Gas sample ports to measure the concentration and pressure } \\
\text { of gases migrating through the bioreactor. }\end{array}$ \\
\hline $\begin{array}{l}\text { Leachate Collection System } \\
\text { Manholes }\end{array}$ & $\begin{array}{l}\text { Flow meters will be installed in each leachate collection } \\
\text { system manhole to continuously measure the flow of } \\
\text { leachate from segregated areas of the landfill. }\end{array}$ \\
\hline
\end{tabular}

Table 2. Summary of monitoring

\begin{tabular}{|c|c|}
\hline Monitoring Activity & Description \\
\hline Leachate & $\begin{array}{l}\text { Samples of leachate will be collected from each manhole on } \\
\text { a routine basis. The leachate will be analyzed for the } \\
\text { following parameters. } \\
\text { pH } \\
\text { Conductivity } \\
\text { Dissolved Oxygen } \\
\text { Dissolved Solids } \\
\text { Biochemical Oxygen Demand } \\
\text { Chemical Oxygen Demand } \\
\text { Organic Carbon } \\
\left.\text { Nutrients ( } \mathrm{NH}_{3}, \mathrm{TKN}^{\mathrm{T}} \mathrm{TP}\right) \\
\left.\text { Common Ions (Cl; } \mathrm{NO}_{3}, \mathrm{NO}_{2} ; \mathrm{SO}_{4}{ }^{2-}, \mathrm{Na}^{+}, \mathrm{K}^{+}, \mathrm{Ca}^{2+}, \mathrm{Mg}^{2+}\right) \\
\text { Volatile Fatty Acids } \\
\text { Organic Priority Pollutants } \\
\text { Heavy Metals }\end{array}$ \\
\hline Gaseous Emissions & $\begin{array}{l}\text { Gas emissions from the landfill will be measured routinely } \\
\text { as part of the operation of the bioreactor for } \mathrm{CH}_{4}, \mathrm{CO}_{2}, \mathrm{O}_{2} \text {, } \\
\text { and } \mathrm{N}_{2} \text {. Samples will also be collected at times to measure } \\
\text { NMOCs, } \mathrm{H}_{2} \mathrm{~S} \text {, and } \mathrm{N}_{2} \mathrm{O} \text {. }\end{array}$ \\
\hline Solid Waste & $\begin{array}{l}\text { Solid waste samples will be collected to directly assess the } \\
\text { degree of stabilization. Parameters to be evaluated include: }\end{array}$ \\
\hline
\end{tabular}




\begin{tabular}{|l|l|}
\hline & $\begin{array}{l}\text { Moisture content } \\
\text { Volatile Solids } \\
\text { Methane Yield } \\
\text { Cellulose } \\
\text { Lignin } \\
\text { On occasion, the waste samples will also be analyzed for } \\
\text { organic priority pollutants and heavy metals (total and } \\
\text { leachable). }\end{array}$ \\
\hline Landfill Settlement & $\begin{array}{l}\text { The bioreactor landfill will be surveyed routinely to measure } \\
\text { the degree of waste settlement (an indicator of biological } \\
\text { decomposition). }\end{array}$ \\
\hline
\end{tabular}

\section{METHODOLOGY FOR MEETING PROJECT OBJECTIVES}

The project goals and objectives were outlined in section 2.0. The description of the demonstration landfill bioreactor, the governing operational plan, and the research activities to be coordinated with the design, construction and operation of the bioreactor were described in sections 3.2, 3.3, and 3.4. This section describes how the project goals and objectives will be met through the project's experimental methodology.

Objective: Design and operate the bioreactor using innovative techniques and concepts.

The bioreactor landfill will be designed, constructed, and monitored with a number of innovative techniques and concepts. While the operation of a landfill as a bioreactor is still a relatively new technology, research in this area has been conducted for a number of years, and some full-scale operations of limited scope have been performed. In addition to further refinement of existing bioreactor concepts at the full-scale, operating landfill level, some new approaches will be utilized.

- A system will be designed to allow the bioreactor to be operated aerobically or anaerobically. Aerobic operation in a large facility will be new, as will be the phasing of anaerobic and aerobic phases.

- A gas collection cap system will be installed in combination with a leachate recycle system, a gas extraction system, and an air injection system.

- Instrumentation will be placed on the landfill liner surface, and within the waste mass, in an innovative manner.

Deliverables:

- Statement of successful placement and operation of instrumentation and equipment.

- Presentation of data from instrumentation in periodic reports. 


\section{- Establish Bioreactor Web Site}

Objective: Design and operate the bioreactor in a manner to control and measure the major inputs and outputs.

A major limitation in the data collected from full-scale bioreactor project to date is the inability to capture and measure all inputs and outputs. This is especially true with gas emissions in both aerobic and anaerobic systems. The landfill bioreactor at the ARAL will be equipped with a geomembrane cap to collect gas emissions from the surface. The leachate collection system will be utilized to monitor gas inputs and outputs. Leachate production will be measured on the basis of each individual leachate collection line. All landfill inputs will be measured using state of the art techniques. Thus all major inputs and outputs will be measured to the best of the project team's ability.

Deliverables:

- Description of inputs and outputs in periodic reports.

- Presentation of data in periodic reports.

Objective: Evaluate the use of aerobic bioreactor landfill technology and compare the aerobic approach to the use of anaerobic bioreactor technology.

As previously stated, the system will be designed in a flexible manner such that it can be operated either aerobically or anaerobically. The impact of each of the technologies will be evaluated by operating some areas of the bioreactor aerobically, while others are operated anaerobically. The impact of these operation schemes on the bioreactor process will be measured through the instrumentation and monitoring described in Tables 1 and 2 .

Deliverables: Presentation of data in periodic reports.

Objective: Instrument the landfill bioreactor to permit in-situ monitoring of bioreactor activity and to measure previously unmeasured information (e.g. leachate head on the liner).

Instrumentation will be installed for in-situ monitoring of landfill parameters. This instrumentation includes transducers for measuring head on the liner, and monitoring probes for measuring waste temperature and moisture content. Additional information on instrumentation is presented in Table 1.

Deliverables:

- Statement of successful placement and operation of instrumentation and equipment.

- Presentation of data in periodic reports. 


\section{KALMAR ECO-TECH'03}

Bioremediation and Leachate Treatment

KALMAR, SWEDEN, November 25-27, 2003

Objective: Monitor the bioreactor in a manner that measures the impact of bioreactor activities and to allows the control of the waste treatment process (e.g. leachate and gas composition and generation, waste characteristics, settlement).

The landfill will be monitored to measure the impact of bioreactor operations on the treatment of landfilled waste. This will also provide a mechanism to assess and control the waste treatment process. Leachate quality will be routinely measured to address the impact of operation on leachate quality and potential leachate treatment costs. The composition of gaseous emissions will be routinely measured, as will the settlement of the waste mass and the degree of biological stabilization of the solid waste. The parameters measured will be used to control the waste treatment process. For example, temperature and gas concentration will be measured using the monitoring probes as a means to evaluate and control the rate of air injection into a given area of the landfill.

Deliverables:

- Models for use in generating protocols for controlling the waste treatment process.

- Protocols for controlling the waste treatment process

- Methodology for quantifying settlement.

- Presentation of data in periodic reports.

Objective: Collect data through instrumentation, field monitoring, and laboratory analysis that will enable the project team to assess the success of the project, the feasibility of this technology for other sites, and to enable the future design and operation of landfill bioreactors in Palestine.

The data collected through the instrumentation (Table 1) and field/laboratory monitoring (Table 2) will be used to assess the success of the project. The rapid stabilization of the landfilled waste will be determined by measuring gas production, landfill settlement, and waste decomposition. Diffierent treatment strategies will be evaluated for relative success in this manner.

Deliverableso

- Presentation of data in periodic reports.

Objective: Develop standardized design and operation procedures for this technology.

The researchers will develop standardized design and operating procedures using the data collected from the study. This will also include the collection of data to allow the development of engineering models for bioreactor landfill simulation. Design procedures include the design of injection and extraction wells, spacing of such wells, design of leachate collection systems in bioreactor landfills, and the design of a gas collection cap.

Deliverables:

- Models for use in generating protocols for standard operating procedures 
- Standard operating procedures

- Simulation models for physical, chemical and biological processes in landfill bioreactor.

- Presentation of data in periodic reports.

Objective: Further define and quantify the true costs and benefits of landfill bioreactors.

A major goal of the project is to quantify the actual operational costs of the bioreactor landfill, both aerobic and anaerobic. The costs needed to operate a bioreactor will be determined. The benefits will be quantified as much as possible. Expected benefits include increased landfill settlement and the resulting gain in landfill capacity. Other benefit issues to be addressed will include the landfill siting minimization and the possibility of a reduction in post-closure care.

Deliverables:

- Methodology for preparation of cost/benefit analysis

- Periodic cost/benefit projection reports throughout project

- Project's Final Report to include a Cost/Benefit Chapter describing potential impact of bioreactor landfill on post-closure care costs and financial responsibility regulations

Objective: Provide a resource and training ground for students in the State University System, landfill operators, and engineers in Palestine.

In addition to the students directly involved with the project research, the demonstration project will also an opportunity for all students at BZU to learn about bioreactor landfill technology. The DoT will sponsor a series of meetings specifically for BZU students that include both classroom presentations and visits to the site. The project team will also explore other funding sources for summer student coops working on the project.

The information gathered in the project will be disseminated in a manner that will benefit interested landfill operators and engineers. Once the project is established, training courses coordinated by the DoT will be held at the landfill site for landfill operators. The researchers will also provide training courses with special emphasis on design and operating procedures based on the results obtained from the project. The information gathered in the project will be routinely presented to the solid waste community in Palestine, at such forums as technical advisory group meetings. All of the informationo gathered in the project will be made available as part of the project's web site.

Deliverables:

- Schedule and description of training opportunities

- Report on the attendance and results of training opportunities

- Plan for extending training after the project. 
KALMAR ECO-TECH'03

Bioremediation and Leachate Treatment

KALMAR, SWEDEN, November 25-27, 2003

\section{CASE STUDIES ON CLEANER PRODUCTION}

\subsection{Cleaner production in the leather industry}

Tanning industry is considered one of the heavy polluting industries in Palestine. Treatment of animal hides and skins comprises the preparation and processing of this raw material, using large amounts of chemicals and enormous volumes of water and generating significant pollution loads (Shramm, 1997).

In Palestine there are 18 tanneries, ten of them are in Hebron city. The tanneries in Hebron city are all small. Tanning and its associated operations can be a source of considerable environmental impact. Air and water pollution, widespread odors, poisoning from toxic gas, and unsafe disposal of waste are among the problems that have been experienced to a greater or lesser extent in the tanning industry. Industries today must remain profitable in an increasingly competitive world, while accounting for the environmental degradation caused by their production processes and products. Cleaner production meets this dual objective (UNEP, 1991). Low cost modifications to current tanning practices can potentially reduce the pollutants and waste materials discharged with the solid waste and wastewater streams.

Conceptually, pollution prevention has always been simple. Find the source of the environmental problem, and change the source to reduce or eliminate the problem. The objective? To reduce risk to workers, communities, and the environment by preventing pollution where it is first generated. Operationally, pollution prevention has been defined as the top of an environmental protection hierarchy, and is followed, in order, by recycling, treatment, and disposal (USEPA, 1992).

The environmental impacts of the tanning industry are generally significant with outputs of wastes, i.e. high concentrations of organics, salts and heavy metals (chromium), both in solid and liquid form as a result. In order to bring the tanning industry more in line with present environmental thinking, various methods have been devised to reduced impacts.

Nazer et al., (2004) proposed a modification method for the unhairing-liming of hides where the unhairing-liming liquids were reused several times after adjustment of the needed concentrations of chemicals. The study, aimed also at reducing the costs of the unhairing-liming process.

Experiments were carried out at lab-scale with a simulation apparatus designed for the purpose. The present value approach was used to evaluate the economic feasibility of the modified method. It was found that the modified method required some investment in new equipment and was a little more labor intensive as compared with the conventional method. However, the modified one revealed savings in water and chemicals as well as reductions in wastewater treatment cost. The modified method allowed for five times reuse of the unhairing-liming liquor without affecting the quality of the final product. 
KALMAR ECO-TECH'03

Bioremediation and Leachate Treatment

KALMAR, SWEDEN, November 25-27, 2003

\subsection{Environmental Impact of COD and wastewater production}

It can be seen that the average COD loads emitted per ton of hides were reduced when the effluent of the unhairing-liming process was recycled and reduced quantities of chemicals were added. It was also found that by increasing the number of times the process water was used (cycle number) the average concentrations of COD were decreased (Figures 2).

It was found that the average water consumption per ton of hides was reduced when implementing the modified unhairing-liming method. It was also noticed, that a decrease in the wastewater production, as water consumption was decreased.
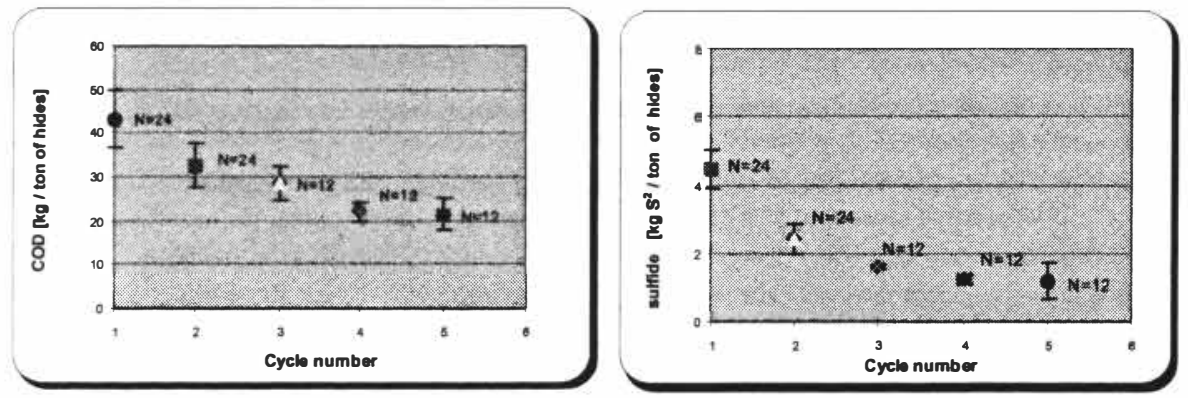

Figure 2. Relation between COD load emitted per ton of hides and number of times the process effluent was used (cycle number). $N=$ number of samples. COD values are as mean (standard deviation).

Figure 3. Relation between sulfate loads emitted per ton of hides and number of times the process effluent was used (cycle number). $N=$ number of samples. Sulfate values are as mean (standard deviation).

The net present value method (NPV) was used to evaluate the feasibility of the modified method. All calculations are carried out for a tannery processing one ton of hides per day and working 250 days per year taking into consideration the weekends, national and religious holidays. The results revealed that more than 10000 US\$ can be saved by adopting the modified method with five cycles compared with only one cycle. Our case on cleaner production could be applied in a similar way to reduce solid waste streams or to utilize alternative raw processing materials in order to minimize landfilling of waste loads.

\section{CONCLUSIONS}

Bioreactor landfill technology is being successfully employed in a number of locations throughout the world, and its superior properties compared with conventional dry landfills are eaming the acknowledgement of communities and decision makers. Developing countries have particularly serious problems, related not only to lack of 
adequate sanitary landfills but also to lack of cleaner production applications. Cleaner production techniques have been employed for a long time, and various approaches and success stories have resulted, but the skilful use of waste minimization techniques and other unused recyclable materials will become more important in the future. Bioreactor landfill is a unique technology, developed based on technologies for handling combustibles and supported by numerous successful experiments in waste processing. Based on the data presented in this paper, five concepts were identified as top priority research needs in the landfill area to be addressed by the Palestinian solid and hazardous wastes related institutions. These needs are the followings:

- Leachate and gas characterization, quantification and management

- Innovative design, evaluation, and performance of landfill liner systems

- Optimization and management of landfill operations

- Environmental monitoring of municipal solid waste landfills

We firmly believe that bioreactor landfill technology can contribute to life expansion of old dumpsites and improve environmental sector in developing countries now and in the future.

\section{REFERENCES}

[1] Miller, Townsend, Earle, Lee and Reinhart (1994). Leachate recycle and the augmentation of biological decomposition at municipal solid waste landfills. Presented at the Second Annual Research Symposium of the Florida Center for Solid and Hazardous Waste Management, Tampa, Fla.

[2] Nazer, D., Al-Sa'ed, R., and Siebel, M. (2004) Development of a modified method for reducing the environmental impact and economics of the unhairing-liming process in the leather tanning industry. J. Cleaner Production, (accepted; in revision).

[3] Reinhart and Townsend (1997). Landfill Bioreactor Design and Operation. CRC Press, Boca Raton, Fla.

[4] Schramm, W. (1997). New findings on the generation of waste and emissions, and a modified cleaner production assessment approach-illustrated by leather production. J. Cleaner Prod. 5(4): 291-299.

[5]

[6] Townsend, Miller and Earle (1995). Leachate recycle infiltration ponds. J. Env. Eng., ASCE, 121(6), 465-471.

[7] UNEP (1991) Tanneries and the Environment: A Technical Guide. Technical Report Series No. 4, United Nations publications. Paris, France. pp.15-39.

[8] USEPA (1992). Facility Pollution Prevention Guide. EPA/600/R-92/088, US Environmental Protection Agency, Office of Research and Development, Washington DC. 